\title{
Gilles Deleuze and Early Cinema: the Modernity of the Emancipated Time
}

\begin{abstract}
Although the transition from the movement-image to the time-image is one of the most commented upon Deleuzian problems, Gilles Deleuze neglected the previous transition from 'images in movement' to the first regime of the movementimages. As my approach will be transhistorical, focusing especially on early silent movies and recently expanded cinema through early moving images (Lumière Brothers) and 1970s structural films (Malcolm Le Grice), I will reflect on how we can think time and moving images outside of this closed Deleuzian movement-image/time-image conceptual framework. In other words, we can ask: How to expand this conceptual framework? Drawing on David Martin-Jones' 'attraction-image', my aim is to explore the role of early cinema and the reasons for Gilles Deleuze's own historical and technical (mis)judgement of early silent cinema. In this sense, the emergent studies on the history of early silent movies, and the growing field of Deleuzian studies on film, together have an important role on the philosophical and historiographical analysis of film's expression of time and modernity.
\end{abstract}

Keywords: Gilles Deleuze, David Martin-Jones, Philosophy of Film, Early Cinema, Lumière, Malcolm Le Grice.

\section{On Early Cinema: What was Cinema to Philosophy?}

The transition from the semiotic regime of movement-image to the semiotic regime of time-image is one of the most commented upon Deleuzian problems (Rodowick 1997b). ${ }^{2}$ Gilles Deleuze, in Cinema 1 and Cinema 2, wrote extensively about the causes for this transition, considering it a necessary evolution of the cinematographic art. When Deleuze mentions that 'today' the pretension of the pioneers of cinema raises a smile for its naivety (i.e., that they could change the viewer's mind by provoking a shock in thought), by 'pioneers' he means Dziga Vertov, D. W. Griffith, and Abel Gance. Throughout the twentieth century, cinema was usually compared either to 'the mechanism of conceptual thought' (Bergson 1922, 287) or identified as the art of making us think (Deleuze 2000, 366). Some of the first film theorists would see cinema as a new and different type of visual art that would have a special connection with thought, even if not necessarily with the philosophical thought. Deleuze himself 
followed this line of research, and as a result, he started to think about the movementimages regime, having in mind three potential moments of the possible relationship between images and thought. For the sake of argument, in the present essay I will only develop the first movement in detail, which goes from images/percepts to thought/concepts (Deleuze 2008, 152-153). This movement is that of a critical thought or noochoc, namely, it is the result of the work of montage and the indirect representation of time, of which we can find in Sergei Eisenstein's films one of its main representative cinematic moments. The shock derived from the assemblages of images is the synthesis created by the dialectics between images that make us think, either by their rhythmic, metric, tonal, overtonal, or intellectual montage. In this case, the opposition between those images makes us think the Whole, a Whole that is not perceived neither by each individual image nor by their assemblage, but can only be thought indirectly after the resulting montage (Deleuze 2008, 158).

If the perception-image is the first avatar of the movement-images regime - of what could be, according to Deleuze, a cinematic version of George Berkeley's philosophical esse est percipi aut percipere -, then in which sense can we apply that concept to the Lumière Brothers, to Méliès, to Émile Cohl, or to Edwin Porter? When was the art of moving images regarded as an art of becoming visible and audible, an art of becoming perceived? Thus, the question on the transition from 'images in movement' to the movement-images regime brings us to the core of a specific issue concerning the nature of the cinematic art: what was cinema, from an ontological point of view? How did pre- and post-cinema delimit cinema's own boundaries? How can we expand this conceptual framework? Moreover, how (using which criteria?) can we delimit pre- and post-cinema after all?

A philosophical analysis of those first short films will allow for a better understanding of the philosophical aesthetical value of those images, namely a better understanding of the relation between technology, industrial art, and the artistic intention, or a 'will to art' (Pisters 2012, 255). We focus on a type of film that has only been recognized to have narrative structure within the last thirty years (Gunning 1986, 63-70). Because of this recent historical knowledge of early silent movies, can we simply extend the concept of perception-image to all early cinema, thus including this period in Deleuze's first semiotic regime? Instead of imposing a readymade concept that was created by Deleuze under specific aesthetic, historical, and formal conditions to other aesthetic, formal, and historical ones, we will need another concept to approach the films made by Auguste and Louis Lumière, Méliès, Émile Cohl, and Edwin Porter. 
Such was precisely David Martin-Jones' purpose when he geographical and historically expanded Deleuze's set of cinematic examples without producing a mere application of ready-made concepts, created by Deleuze with another set of examples, geographically and historically circumscribed (meaning, the Eurocentric approach). In this sense, a mere application of old concepts to new cinematic objects would simply perpetuate such Eurocentrism (Martin-Jones 2011, 7). Even if Deleuze did not discuss early silent movies, we need to question the rightfulness of doing that type of analysis and decide upon the best methodology that remains Deleuzian-friendly. According to Martin-Jones, its absence fully justifies this approach, especially if (we could even say, only if) we provide a constructive critique of Deleuze's own work.

According to Ian Jarvie $(1999,418)$, both the depreciation of cinema and the lack of a consistent and continuous philosophical study during the twentieth century are due to the persistence of the analogy between cinema and the Allegory of the Cave. Just like the prisoner, the film viewers seem to have their intellectual activity reduced, manipulated, and passively conducted by those images that they receive uncritically, blindly. In this sense, cinema will correspond to the art of illusion and deception, the art of phantasmata and its spectral reproductions (Georges Méliès is L'hommeorchestre/The One-Man Band [1900]).

At which point did cinema start? With montage? Méliès edited the film itself without cuts. In addition, montage in its classical definition, is an abstract time incompatible with the real duration. With narrative? Edwin Porter's Great Train Robbery (1903) has narrative structure, changes of shots, close-ups, and direct looks into the camera. With the mobile camera? The mobility of the camera does not change cinema at its technical basis because cinema remains, with or without the mobile camera, a succession of immobile sections with an abstract time. In pre-Cinema films, we find a sense of composition and scale, travelling shots, deep focus, and out of field, diagonal perspectives and angles as well as meta-fictional elements. Tom Gunning, for example, highlights the historic context of the first cinema sessions because at a glance we tend to comprehend its spectators as naïve, credulous, and unsophisticated audiences as described by Georges Sadoul or Maxim Gorky. The persistent use of the adjective "primitive" for cinema is due not only to a misconception of a period considered as the “elementary or even childish mastery of form' (Gunning 1989, 4), but also to a general ignorance about the true work of those filmmakers within the context of visual illusions. When we think of early cinema as a collection of short autonomous films with only one 
single shot, we neglect the fact that that shot may not be a representation of reality but an illusion resulting from transparent work.

\section{What has Cinema been? On its Conceptual Limits}

How can the boundaries between 'images in movement', 'movement-images', and 'time-images' be defined within the Deleuzian conceptual framework? According to Deleuze, 'montage, the mobile camera and the emancipation of the view point' were responsible for the evolution from the regime of 'images in movement' to the movement-image regime. Does this mean that, because of this positive definition of 'cinema', we may then negatively define early cinema by the lack of some (if not all) of those qualities? Can we define early cinema as not having montage, neither a mobile camera nor an emancipated viewpoint? In which sense can we defend that the early silent movies constitute the pre-history of cinema, a previous age of non-cinema, or even of a 'primitive cinema' (Deleuze 2009, 27)? Deleuze states that the transition of semiotic regimes, from the movement- to the time-image, happens with the breakdown of the sensory-motor schema of cinema at the end of the Second World War. However, at the same time, he also mentions the names of Japanese filmmakers Kenji Mizoguchi and Yasujiro Ozu to illustrate the evolution of the movement-image towards the timeimage. On Ozu's films, for instance, Deleuze $(2008,13)$ states: 'Ozu built up in a Japanese context a body of work which was the first to develop pure optical and sound situations. [...] remains the inventor of opsigns and sonsigns.' The inquiry into this paradox gives us another perspective on the accuracy of Deleuze's position towards the Second World War as the event that punctuated the transition and the evolution from the movement- to the time-images. As we will see, it also contributes to the suspicion that his idea of early silent movies was archeologically and historically inadequate. Indeed, Deleuze defended that this specific historic event provoked a breakdown of the form of cinema centred on the movement of characters and objects towards 'the dispersive situations, the deliberately weak links, the voyage form, the consciousness of clichés, the condemnation of the plot' (Deleuze 2009, 214) - all formal and aesthetic circumstances that thereafter will distinguish the movement- from the time-image. It overthrows the supposed well-established difference between cinema and pre-cinema. After all, these two regimes share moving images centred on the movement of characters and objects, as an indirect image of time. The frame is conceivable in terms of its geometrical inner positions along with its angle of framing. 
In 1956, Edgar Morin denoted cinema with a distinction that for decades persisted in the theory of cinema as a misunderstanding: the Lumière's films were the representation of realism and Méliès' of unrealism (Ezra 2000, 77). Their films were then seen as a reproduction of life as it is and, on the contrary, Méliès' films were seen as a manipulation and creation of another eccentric reality. Thus, La sortie de l'usine Lumière à Lyon/Workers Leaving the Lumière Factory (Louis Lumière, 1895) takes us to real life and to the way that we naturally perceive it. In this case, it takes us to the naïve pretension of representing reality as it is and as we would perceive it. As we will see, in the past thirty years film historians and theorists such as Tom Gunning (2002) and Thomas Elsaesser (2004) no longer consider film's historical material just as an objective representation of events as such. As stated before, the perception-image is 'the first avatar of the movement-image' and it raises as:

[A] very strange kind of subjectivity, a subjectivity with no background or backdrop, and a subjectivity that lives entirely in the present, as it were, reacting and responding only to filmic events as they happen. If these are subjective images, then they are certainly not images guided by a subject. Rather, they are the responses of a subject that has lost all subjecthood, that has lost the traits of agency and selfdetermination. (Rushton 2008, 128)

Although Deleuze's idea of these inhuman perceptions does not aim to create a phenomenological theory of the spectator (of someone that perceives those moving images), he wished to think differently about the relationship between a subject and an object, between percipere and esse percipi. If a potential centred subjectivity is lost, let us focus ourselves on the images: before moving images went into movement-images, they were self-reflexive and had been since their inception. We can see in some of the pioneers' films (think, for instance, in Démolition d'un mur/Demolition of a Wall [1896], directed by Louis Lumière) that film has always been self-reflexive. Film has also always been self-moving images, independent of any spectator.

The transition from the 1970 s to the ' 80 s was marked by a shift concerning the classical idea of what early cinema was and what its aesthetic value was: pre-Griffith cinema was not considered worthwhile of any analysis or artistic thought. The 1978 FIAF (The International Federation of Film Archives) Brighton Congress would change film studies forever. The description of spectators screaming and running from the cinema theatre (Lumière and L'arrivée d'un train en gare de La Ciotat/The Arrival of a Train [1895]) reminds us of the mystic explanation of the first pre-historic cave images. Actually, the point of view that stresses the spectator's passivity will be crucial to the 
consequent moment in cinema's history when cinema was used as a powerful tool to manipulate the masses. Recent "media archaeological" (Elsaesser 2004) investigations on that period, however, show us that the viewer had the idea of being present to a modern technological mechanism of entertainment. Congruent with that fact, to most of those viewers there was a rational conflict between what they knew they were watching (a magic trick) and what they were seeing (the illusion, the trick itself). By then there was neither complex narrative structure nor empathy with one character, there was no immersion, but the spectators were confronted with shock, the unexpected, and told they must understand that the actors had consciousness of their act of seeing (as a "scopic pleasure"). Besides that consciousness, actors looked directly into the camera and a host narrated the film as it was projected, explaining it to viewers. Its artistic interest was in seeing an illusion that created so many sensations (such as astonishment, originality, mystery, fear, and pleasure). This included the pleasure itself of knowing how the trick worked. According to Tom Gunning (1995, 129): 'The audience's reaction was the antipode to the primitive one: it was an encounter with modernity.' What could leave the spectator speechless was not the illusion of reality, meaning the real train arriving at the train station, but the nature of the illusion itself - the power of the still images' movement. As Gunning has defended (1989, 3-12), it is precipitated to connect the cinematic realism and non-fiction to the Lumière Brothers' work and the cinematic unrealism and pure fiction to Méliès' films. The Lumière Brothers were not exclusively interested in everyday real events, in documenting how private life (with home videos such as Le repas de Bébé/Baby's Meal, Louis Lumière, 1895), and work (La sortie de l'usine Lumière à Lyon/Workers Leaving the Lumière Factory, Louis Lumière, 1895, and Laveuses sur la rivière/Washerwomen on the River, Auguste and Louis Lumière, 1897) were at the end of the nineteenth century (in this sense, film provided historiographical evidence not only of great events, but also of the ordinary people's unimportant familiar and social events). They also enacted staged events with special effects (Démolition d'un mur/Demolition of a Wall, 1896) and shot comedies and gags as well (L'Arroseur arrosé/The Sprayer Sprayed, 1896). More than naturalism, they sought the realism of the fixed single shot equivalent to the spatiotemporal continuity of our everyday natural perception. Even if the diegetic world created by Méliès was fictional, the registered elements were real, as real as in Lumière's. In the conclusion of her book on Méliès, Elizabeth Ezra (2000, 149) examines some of the myths surrounding his work: not only did he direct fantasy films, but his movies were also more than theatricals. He used exclusive cinematic techniques that we associate to 
montage-film of the twentieth century, special effects such as substitution splicing, close-ups, and multiple exposure (surimpression) (as the dissolve, matte shot, replication effect or superposition (L'homme-orchestre/The One-Man Band, Georges Méliès, 1900), transparency), not to mention continuity editing, thus denoting a profilmic and post-production care (Ezra 2000, 28-33).

In this sense, the phenomenological realism defended by André Bazin highlights the problem of the definition of the cinematographic art in its photographic nature. If in a first level of representation, photography remained as an inferior copy of reality when compared to some of the elements presented in painting (it was colourless, for instance), that absence was easily explained by its transparent objective nature, independent of any human intervention (it was only a mechanical record). Nicéphore Niépce, Auguste, and Louis Lumière have freed art from its obsession with likeness (Bazin 1967, 12).

Deleuze has founded his philosophy of film by going directly from snapshot photography and the studies on movement to the montage-film. It is well known that Henri Bergson and André Bazin's influence are at the core of this position.

\footnotetext{
The shift which Deleuze perceives in Cinema 1, from primitive cinema to movement-image - itself a product of his engagement with Bergson as opposed to a conclusion reached by examining early silent cinema - looks rather different when examined archaeologically, and contextually, rather than as an apparently linear, evolutionary development of film form. (Martin-Jones 2011, 42)
}

Indeed, through the recent work of film historians, in particular André Gaudreault (1984) and Tom Gunning (1989, 1995), we know that these pioneers created nonrealistic narratives through an indirect representation of time. For Deleuze $(2008,40)$ : 'The direct time-image is the phantom which has always haunted the cinema, but it took modern cinema to give a body to this phantom'. Early cinema not only had not the intention of natural narrative, as montage per se was not the cause of such narrative awareness, as Deleuze $(2009$, 32) believed: 'for the narrativity flows from this conception of montage.' However, even in scholars such as Gunning, the cinema of attractions would exclude some of the film's narrative contents, as he only focuses on the immediate elements of the spectacle. That is why Martin-Jones' effort consists of an encounter between the cinema of spectacle, narrative, and non-editing montage. Expanding Deleuze's taxonomic system, it is appropriate to rethink the true pioneers of cinema. To determine this moment of transition along with its categories, it is essential 
to see pre-cinema, in the sense of pre-montage-film, as a test to the first avatar of the movement-image, the perception-image.

\section{Henri Bergson's Criticism on Cinema}

Recent archival research material from film history shows us the historiographical limitations of Gilles Deleuze's knowledge of film history and film practice: he_did not consider the historical period of cinema that he called 'pre-history cinema' and 'primitive cinema' to be important. To this, we may add that his Eurocentrism and lack of knowledge of other cinemas from other geographies, with other production and distributions contexts. The effort of David Martin-Jones to expand Deleuze's framework to other cinemas, both in time and space, however, is effective in this context. How to think moving images before the movement-images? As Deleuze clearly neglected this period, we have to decide which methodology is better for conceptualizing it. To apply Deleuze's conceptual work as a closed system to new contexts, new filmographies, is a way of extending such a closed system. However, we would not be opening his taxonomic work, thus acquiring a clearer idea of his reasons to understand this period as pre-cinema or primitive cinema. Although we might say that 'following a classical film theory paradigm, Deleuze overstresses the importance of montage' (Rodowick 1997a, 214), according to Bazin, the technique of montage was indeed cinema's 'true essence' (which was at the basis of the Deleuzian definition of movement-image).

According to Bergson, the 'cinematograph's illusion' or 'false movement' was not but a poorer analogy to our natural perception. ${ }^{3}$ If Henri Bergson appears in Deleuze's 1956 texts as a philosopher creator of concepts, he then regains the status of nothing more than a philosopher of film. ${ }^{4}$ In The Movement-Image, Deleuze begins by recuperating and deflecting Bergson's criticism of the moving images expressed in Creative Evolution from 1907. Instead, he relates it to one of Bergson's previous books, Matter and Memory, from 1896. In this way, Deleuze defends that Bergson has invented the 'concept' of cinema even before its historical technical invention (2009, 3). As we will see, the odd part in this anachronistic method is not the fact that Henri Bergson had mentioned cinema in his books, thus understanding the philosophical interest of this new art form since its outset. Rather, what is odd is the fact that Deleuze was capable of establishing his own philosophy of film by choosing one book that makes no mention at all to cinema (Matter and Memory), and not a book that actually mentions cinema, 
although to criticize it (Creative Evolution). Deleuze goes further in his interpretation claiming 'the Bergsonian discovery of a movement-image, and more profoundly, of a time-image'; and, even with Bergson's further criticism on cinema, he claims, 'nothing can prevent an encounter between the movement-image (...) and the cinematographic image' (Deleuze 2009, xix).

We have to face Deleuze's anachronism, and the fact that even if it is highly probable that Bergson was indeed aware of the movement-images and the mobile sections, his ideas on the immobile sections and the spatialized time lead him to understand the cinematograph as false movement. It was not his ideas on the mobile sections or moving-images, as Deleuze (2009, 3) insists: 'The discovery of the movement-image, beyond the conditions of natural perception, was the extraordinary invention of the first chapter of Matter and Memory.'

In order to create his series of prefixing $\mathrm{X}$-images, Deleuze follows the Bergsonian model of the 'recollection-image'. Considering what an 'image' is to Bergson, we now realise how Deleuze was mistaken with this method because Bergson would not agree that we could make images of real movement or of real duration (durée). Matter and Memory devalues the traditional distinction between materialism and idealism claiming that an image is everything that we perceive when we open our eyes; it is a matter-image (Bergson 2008, 11). Bergson diagnosed a crisis in psychology as a movement that could no longer be an external element and image could no longer be understood as internal. However, as matter-image, it includes a virtual and an actual reality, both conscious and unconsciousness. In his philosophical system, we have perception-images and concept-images: the concept is nothing but an abstraction, an image of another image, in a conceptual process that gradually departs from the perception-image (Mullarkey 1999, 7). Real change is unceasing, but our mind naturally has a habit of fixing that change through conceptual thought. Thus, the immobile form of thinking is not appropriate to the reality of becoming, but is appropriate to our way of thinking it - actually, it is our only way of thinking.

In his Cinema books, Deleuze went directly from snapshot photography and studies on movement from Étienne-Jules Marey and Eadweard Muybridge, to the montage-film of D.W. Griffith and Sergei Eisenstein. When analysing this specific period, the evident gap of circa twenty years of film history seems to mean that Deleuze did not have the sufficient criteria to analyse movies previous to 1915 , the year of the most acclaimed montage-film, The birth of a nation by D. W. Griffith. Deleuze's first reference to pre-cinema filmmakers occurs in his first commentary on Bergson: 
[...] what was cinema's position at the outset? On the one hand, the view point was fixed, the shot was therefore spatial and strictly immobile; on the other hand, the apparatus for shooting was combined with the apparatus for projection, endowed with a uniform abstract time. The evolution of the cinema, the conquest of its own essence or novelty, was to take place through montage, the mobile camera and the emancipation of the view point, which became separate from projection. The shot would then stop being a spatial category and become a temporal one, and the section would no longer be immobile, but mobile. (Deleuze 2009, 3)

However, Deleuze also admits an exception to these rules: 'the movement-image in itself only rarely relates do the mobility of the camera, but arises more frequently from a succession of fixed shots which presupposes montage' (2009, 30). As Rodowick and Martin-Jones have pointed out, the interval between Bergson's 1896 Matter and Memory and his 1907 Creative Evolution is the same interval of early silent cinema that was not analysed by Deleuze (Rodowick 1997a, 19, Martin-Jones 2011, 25).

Bergson mentions the 'cinematographic illusion' as the creation of 'false movement'. Deleuze mentions this historic interval as that of 'primitive cinema' and 'pre-cinema'. Although he has not developed what he understood for 'primitive cinema', Deleuze himself was attentive to 'pre-cinema' (in his peculiar sense of premovement-image) and even to the difficulties of delimiting it in historical terms. In Cinema 1, he states: 'When we think about the prehistory of the cinema, we always end up confused, because we do not know where its technological lineage begins, or how to define this lineage' (Deleuze 2009, 5). But even so, he points out four determining conditions: First, the snapshot and Bergson's second lineage of modern science: 'modern science must be defined pre-eminently by its aspiration to take time as an independent variable' (Bergson 1922, 355). According to Deleuze $(2009,5)$ cinema follows this Bergsonian lineage because the images are instantaneous sections at the same time that movement is abstract. On the contrary, snapshots, and both Marey and Muybridge's studies on movement, would belong to the first lineage of ancient science. Second, the equidistance between snapshots. Indeed, cinema seems to be able to play real movement, so, what is its interest to science and to art? None. Third, the transfer of the equidistance to a film (Edison and Dickson). Fourth, the mechanism for moving on images - at this stage, cinema became a type of public entertainment.

Thus, according to Deleuze $(2009,5)$, cinema follows the second lineage because when we apply these four conditions to the first lineage (that of long-exposure photos, or 'privileged instants'), it becomes a system 'oblivious to cinema'; even in animated 
film, we do not have poses or fixed images. Art will reflect the ambiguity between the scientific analyses by any-instant-whatever and the artistic analyses of poses, but both fail to reconstitute movement by immobile cuts or snapshots or by eternal poses. Both systems demand a specific concept of 'whole', either because it is an image of the set or an image of eternity. Studies on movement tend to defend that it is easy to pass from movement to stillness: it is just a question of cutting the spatialized time into fragments. But, we notice that the reverse does not occur: we cannot pass from stillness to movement. How to surpass the gaps (Zeno's paradoxes) between still images? The fluidity of movement is lost as soon as we divide it. Cinema reconstitutes movement by immobile cuts or snapshots and therefore demands a 'whole': it is an image of the closed set or closed system. How overcome this reification? Deleuze suggests that the possibility of duration be understood not as a closed set, but as an opened whole (the third Deleuzian thesis about Bergson's philosophy). However, in the end, the open whole that qualitatively relates and changes the mobile sections is founded on immobile sections - or, what constitutes movement as a mobile section? Accordingly to Mary Ann Doane (2002, 174-176), Bergson was mistaken; the cinematograph was not a modern version of Zeno's paradox. Actually, moving images negate the infinite gap: there is always the next frame and the gap between frames are rescinded by the idea of continuity.

\section{Shadow of a Doubt: Lumière, Le Grice, and Expanded Cinema}

David Martin-Jones took a different Deleuzian path by gathering the concepts of the cinema of spectacle, narrativity, and a non-continuous whole. Although Deleuze would not exclude that the fixed shot (depth of field) could have montage without cuts, he held that moving images were directly connected with the movement of the camera as well as with montage. However, he would reduce montage to two distinct situations: either as indirect or as direct expression of the whole. The first would create movementimages with a continuous montage of mobile sections; the second, the time-image with discontinuous montage, interrupted by the interstice. Once Deleuze tries to adopt his thought on cinema to Bergson's own criticism to the cinematograph as a false movement, he will privilege montage in order to avoid the issue of abstract time and immobile sections. This privilege given to montage does not allow him to consider early cinema prior to montage-cinema because montage will perfectly serve his concerns regarding how time is represented. 
The solution of Martin-Jones was to depart from this definition of montage, beyond the continuous time of the movement-image and the discontinuous time of the time-image, and to defend a non-continuous time of early cinema, thus recuperating Tom Gunning's idea about Georges Méliès' 'non-continuous montage' (1984, 102112). What changes is the comprehension of early cinema as the art of one only fixed shot. The spectacle is created by tricks, without the movement of the camera, as Deleuze would erroneously think. Just like all movement-images, Martin-Jones' 'attraction-image' is an indirect expression of time as duration, but contrary to the movement-image, it does not intend to create the illusion of space-time continuity based on the sensory-motor schema. Although the concept of attraction-image finds its roots in Gunning's cinema of attractions, it is not confined to early silent movies, but rather becomes a transhistorical type of moving image. Thus, Martin-Jones opens the cultural and aesthetical contexts of production and cinematographic industry by both geographically and historically expanding Deleuze's scope of analysis. With the concept of attraction-images, he shows that in Méliès we can find movement-images before those outlined by Deleuze. Thus, in my perspective, pre- and post-cinema come closer to each other in a transhistorical perspective that has modernity ${ }^{5}$ as a common ground.

This proximity is clear between Lumiére's L'Arroseur arrosé/The Sprayer Sprayed (1895, 1896) and After Lumière - L'Arroseur arrosé (1974), by Malcolm Le Grice. That way, the grand theory of Cinema 1 and Cinema 2 becomes relative and helps us understand what happens before the movement-image and after the timeimage. But, how did self-reflexive moving images become a momentous of modernity? On the metacinematic specificity of modern moving images, Bruce Isaacs $(2007,165)$ defends: 'Tarantino and De Palma are performing cinema rather than representing a non-cinematic Real. The several quotations function as a stream of metacinematic dialogue'. What if cinema is considered as always being metacinematic and serial? Preand post-cinema would come closer in this transhistorical perspective. For instance, how do L'Arroseur arrosé/The Sprayer Sprayed and After Lumière make us think not only about moving images, the spectator and film techniques, but cinema itself? How do those images make us think cinema when 'to make us think' is, Deleuze supports, a function of the time-images? These two examples seem to be perfect to conceive Bergson's concept of duration both as flux and 'as representative of Time in which all fluxes are engulfed' (Deleuze 1988, 82). Mentioning Marcel Proust, Deleuze (2008, 37 - 
38) defends: 'Proust indeed speaks in terms of cinema, time mounting its magic lantern on bodies and making the shots coexist in depth. It is this build-up, this emancipation of time, which ensures the rule of impossible continuity and aberrant movement'.

L'Arroseur arrosé/The Sprayer Sprayed is an 1895 short film directed by Louis Lumière and is normally considered the first comedy film ever made. Malcolm Le Grice's structural films After Lumière - L'Arroseur arrosé (1974, 12', four screens) are a video installation based on Lumière's film. It consists of four sequences that precisely re-enact this film. If the Lumière's films were circa 40 seconds, in this case each sequence has approximately 3 minutes. The first sequence (Fig.1a and Fig.1b) ${ }^{6}$ is a silent black and white positive sequence where we can see the same plot of the original (a gardener is watering a garden when a boy treads the hose) with a new element - a woman that talks with the gardener. The camera is fixed all of the time (and we do not really see the gardener punishing the kid because they are off-screen).

Fig.1a - After Lumière - L'Arroseur arrosé

(1974) by Malcolm Le Grice (screenshot)
Fig.1b - After Lumière - L'Arroseur arrosé

(1974) by Malcolm Le Grice (screenshot)

The second (Fig.2a and Fig.2b) is a black and white negative sequence accompanied by a piano soundtrack by Erik Satie, Gnossienne No. 1, Lent. The entire scene is filmed with zoom and a moving camera, and only apparently could be a negative version of the first sequence.

Fig.2a - After Lumière - L'Arroseur arrosé

(1974) by Malcolm Le Grice (screenshot)
Fig.2b - After Lumière - L'Arroseur arrosé

(1974) by Malcolm Le Grice (screenshot)

It is followed by a third colour negative sequence (Fig.3a and Fig.3b) to which an audio montage of the same piano music is added along with what seems to be a playground with kids playing. In this case, the fixed camera moves in order to reframe the centre of the action.

Fig.3a - After Lumière - L'Arroseur arrosé (1974) by Malcolm Le Grice (screenshot)
Fig.3b - After Lumière - L'Arroseur arrosé (1974) by Malcolm Le Grice (screenshot) 
There is a final sequence on colour positive film (Fig.4a to Fig.4c) taken from a different point of view: the camera is inside the house where the woman (a character that does not appear in the Louis Lumière film) plays Satie's piano music and from where we can see the child outside annoying the gardener. The entire mise-en-scène is filmed with zoom and a moving camera without leaving the house.

Fig.4a - After Lumière - L'Arroseur arrosé

(1974) by Malcolm Le Grice (screenshot)
Fig.4b - After Lumière - L'Arroseur arrosé (1974) by Malcolm Le Grice (screenshot)

Fig.4c - After Lumière - L'Arroseur arrosé

(1974) by Malcolm Le Grice (screenshot)

Thus, we have different versions that play with film material, diegetic and nondiegetic sound, camera's movements, and spectator's certainty. As we can immediately understand in Le Grice's After Lumière, it is not that it just consisted on four different visual versions of an original early cinema film, but it is four different performances with different frames, angles, camera movements, and audio and visual assemblages. The film also plays with the connection between diegetic and non-diegetic sound and the spectator's expectations. Even the fourth sequence exceeds the natural expectations of the viewer, as it seems to be the first performance seen from another point of view, even though it is not. Variations are inside the image, within its elements, but it is not a variation about the original film, but instead it is inspired by it.

One of expanded cinema's main philosophical interests ${ }^{7}$ is to reveal the moving images as they are, not to hide them as in classical invisible montage and narrative structure, typical of classical Hollywood. The opacity (the denial of cinematic illusion) is revealed by the relationship between filmmaking, production, screening, and perceiving by projecting moving images outside the screen frame. Le Grice's background goes back to his first art works on painting and music. In the second and third sequence, the spectators are expected to understand music in its conventional use as if the sound would be non-diegetic (just as in the classical use of a film soundtrack). The fourth sequence reveals the intradiegetic nature of music, played from inside the house; however, it is a false repetition shot and not the sound that supposedly the gardener and the child would be listening to live. Thus, concerning the possible audio and visual 
assemblages, we realize that the director plays with all the potentialities of diegetic/nondiegetic sound, and on screen/off screen sound: 'Our discovery of the true nature of the music is achieved by a process of repetition and a change of camera perspective' (McMahon, 2006). With Le Grice's recent The Chronos Project (2010), he aimed at understanding the temporal construction of moving images as a matrix of connecting images. Le Grice follows the first cinematographic movement theorized by Deleuze that goes from images to thought, or in his particular case, from sensations to ideas. In his expanded films, sensations of colours, sounds, figures, and narratives are at the origin of experimental meta-cinematographic films that disregard their unique intellectual cerebral quest. By reducing, and eventually eliminating, all cinematic illusions (the identification with characters, narrative continuity and representational realism), 'the image source increasingly became the physical materials and processes of cinema' (Le Grice 1989, 63-64).

Variations are not versions. In Malcolm Le Grice's case, we cannot say that the Lumière's film is at its origin. This way, the first sequence would not be a remake. As well, the other three sequences would be marked by the repetition of something that was never the original, but a remake. Le Grice's art performs cinema's history, creating a metacinematic and serial dialogue with the new film history beyond the mere narrative organization of images. This means that even the history of film is not to be imprisoned under this narrative structure (surpassing by that the restricted need to recover the chronological past only for archival purposes). The focus is on the spectator and the need to structure the film material, thus creating a phenomenological theory of the spectator. As Le Grice $(1989,62)$ says: 'From the beginning of my work with film my predominant concern has been with the spectator. My earliest definition of this problem identifies the general ills of audience passivity, undistanced and unresisted consumption and unconscious psychological compliance with the illusionistic manipulations in dominant cinema. I was concerned to produce an active, conscious and distanced spectator.' To return to Lumière's L'Arroseur arrosé/The Sprayer Sprayed, we cannot state that it was Le Grice's original starting point because Lumière's short film was not the one and only original. The Lumière Brothers would make different variations of their own films, including the one on the topic of a gardener that is watering a garden when a boy treads the hose and causes the comic situation. In the same line of thought, there are other different films on the topic of La sortie de l'usine Lumière à Lyon/Workers Leaving the Lumière Factory (Louis Lumière, 1895), with workers wearing different clothes and settled in evident different seasons of the year. And, at the 
same time, L'Arroseur arrosé (1896) is the sequel of 1895 L'Arroseur arrosé as well as Les joueurs de cartes arrosés (Louis Lumière, 1897) is a comic variation of L'Arroseur arrosé combined with their film Une partie d'écarté/The Messers (Louis Lumière, 1896). The series would go on. Cinema has always been metacinematic and serial - in this sense, it has always been modern.

\section{Final Remarks: On Cinema's Enduring Modernity}

To understand what happens before Deleuze's Cinema 1 and after his Cinema 2 is a way to relativize the supposed closed system of Deleuze's Cinema books. It also provides the opportunity to think about the historic event beyond the chronological transition from the movement-images to the time-images based on the assumption of the impossibility of an inclusive film history, thus questioning the claim of modernity of post-war films. After all, no matter how important it is to think pre- and post-war Europe's culture and mentalities, that event is of a historical and empirical time. As we saw, at its inception, the film spectator was confronted with unexpected images, as assaulted, but always conscious of their act of seeing. By then, it was normal that actors looked directly into the camera. From the beginning, opacity would overcome and deny artistic transparency and cinematic illusion. However, in his analysis, Gunning only focuses himself on the spectacle of these first movies, excluding narrative from that context. Deleuze $(2009,32)$ had a different idea about narrative: montage creates the film narrative. He did not understand montage as a form of narrative or as a technical support to narrative development. For this reason, David Martin-Jones' attraction-image and its implicit historiographical thesis, which aims to demonstrate the limits of a diachronic division between the movement-image and the time-image regime, seemed relevant to a rewriting of a new film philosophy in order to reunify cinema of spectacle, narrativity, and a non-continuous whole, so as to take a different path from Deleuze's closed conceptual system. It is not only a matter of pointing a mistake out, in this case the unawareness of the film techniques used, that would only be discovered by the end of the 1970s by a new generation of film historian and new film historiographical and archaeological studies dominated by different film theories such as Lacanian psychoanalysis, structuralism, and semiology and centred on the Marxist apparatus theory. The unresolved question is that we can find another image of time and movement not embraced by the movement- and time-image conceptual framework in a pre-Griffith epoch. 
Thus, as seen, the modern characteristic of Malcom Le Grice's work does not lie only in structural films or in expanded cinema, but in Lumière: that modernity comes from the Lumière Brothers, from which Le Grice is an inheritor. Le Grice's modernity does not reside in the fact that he creates works of art about other works of art, but in the fact that cinema has always been about itself, as self-reflexive film. This historical shift allows us to understand film modernity before modern cinema, thus dislocating the 'emancipation of time' and giving us another perception of 'impossible continuity and aberrant movement', as meant by Gilles Deleuze. Consequently, within this new philosophical and historiographical model for the film practice, based on the assumption of a non-linear and non-comprehensive history of film, moving images (either conventional cinema or the avant-garde experimental films) are considered metacinematic in a serial dialogue with early cinema within a transhistorical perspective. Malcolm Le Grice's film practice, an attempt to demonstrate the connection between 'film materiality and historical materialism' (Le Grice 1989, 64), is a way of performing this new paradigm alternative to the traditional linear, diachronic, and evaluative history of film. Thus combining and exploring various elements from film medium and film archives, as well as philosophical reflexions on spectator, space, time and the past in his works. By freeing it from a limiting self-referent and nonnarrative paradigm, this perspective renewed the dated Marxist apparatus theory, at the same time that the study of film spectatorship regained some of the political focus it had lost.

\section{References:}

Bazin, André. 1967. What Is Cinema? Vol.1. Translated by Hugh Gray. Berkeley: University of California Press.

Bergson, Henri. 1922. Creative Evolution. Translated by Arthur Mitchell. London: Macmillan.

Bergson, Henri. 2008. Matière et mémoire [1896]. Paris: Presses Universitaires de France.

Bordwell, David. 1997. On the History of Film Style. Cambridge: Harvard University Press.

Colman, Felicity. 2011. Deleuze and Cinema: The Film Concepts. Oxford: Berg.

Deleuze, Gilles. 1988. Bergsonism. Translated by Hugh Tomlinson. New York: Urzone. 
Deleuze, Gilles. 1995. Negotiations 1972 - 1990. Translated by Martin Joughin. New York: Columbia University Press.

Deleuze, Gilles. 2000. 'The Brain is the Screen: An Interview with Gilles Deleuze'. Translated by Marie Therese Guirgis, in The Brian is the Screen. Deleuze and the Philosophy of the Cinema, edited by Gregory Flaxman, 365-373. Minneapolis \& London: University of Minnesota Press.

Deleuze, Gilles. 2003. Desert Islands and Other Texts (1953-1974). Translated by Mike Taormina. New York: Semiotext(e).

Deleuze, Gilles. 2008. Cinema 2. Translated by Hugh Tomlinson and Robert Galeta. London: Continuum.

Deleuze, Gilles. 2009. Cinema 1. Translated by Hugh Tomlinson and Barbara Habberjam. London: Continuum.

Doane, Mary Ann. 2002. The Emergence of Cinematic Time: Modernity, Contingency, the Archive. Cambridge: Harvard University Press.

Elsaesser, Thomas. 2004. 'The New Film as Media Archaeology.' Cinémas. Revue d'études cinématographiques. Journal of Film Studies 14 (2-3): 75-117.

Ezra, Elizabeth. 2000. Georges Méliès. Manchester: Manchester University Press.

Gaudreault, André, ed. 1984. 'Un cinéma sans foi ni loi', Iris - Revue de théorie de l'image et du son/A Journal of Theory on Image and Sound 2 (1) : 2-4.

Gunning, Tom. 1984. 'Non-Continuity, Continuity, Discontinuity.' Iris-Revue de théorie de l'image et du son/A Journal of Theory on Image and Sound 2 (1):102-112.

Gunning, Tom. 1986. 'The Cinema of Attraction: Early Film, Its Spectator and the Avant-Garde.' Wide Angle 8 (3-4): 63-70.

Gunning, Tom. 1989. 'Primitive' Cinema: A Frame-up? Or the Trick's on Us.' Cinema Journal. The Journal of the Society for Cinema \& Media Studies, 28 (2) (Winter): 312.

Gunning, Tom. 1995. 'An Aesthetic of Astonishment: Early Film and the (In)Credulous Spectator', in Viewing Positions: Ways of Seeing Film, edited by Linda Williams, 114133. Rutgers University Press.

Gunning, Tom. 2002. 'Making Sense of Films,' History Matters: The U.S. Survey Course on the Web (February). http://historymatters.gmu.edu/mse/film.

Isaacs, Bruce. 2007. Toward a New Film Aesthetics. London: Continuum. Jarvie, Ian. 1999. 'Is Analytic Philosophy a Cure for Film Theory?' Philosophy of the Social Sciences 29 (3): 416-440.

Le Grice, Malcolm. 1979. 'Towards Temporal Economy.' Screen 20 (3-4): 58-79. 
Martin-Jones, David. 2011. Deleuze and World Cinemas. London: Continuum.

McMahon, Denice. 2006. 'An Analysis of the Soundtrack in the Work of Malcolm Le

Grice.' Senses of Cinema 38. http://sensesofcinema.com/2006/on-movies-musiciansand-soundtracks/soundtrack_le_grice.

Mullarkey, John (ed). 1999. The New Bergson. Manchester: Manchester University Press.

Pisters, Patricia. 2012. The Neuro-Image: A Deleuzian Film-Philosophy of Digital

Screen Culture. Stanford: Stanford University Press.

Rodowick, David N. 1997a. Gilles Deleuze's Time Machine. Durham, Duke University Press.

Rodowick, David N. (ed) 1997b. 'La critique ou la vérité en crise', Iris - Revue de théorie de l'image et du son/A Journal of Theory on Image and Sound 23 (special issue) : 7-24.

Rodowick, David N. 2007. The Virtual Life of Film. Cambridge: Harvard University Press.

Rushton, Richard. 2008. 'Passions and Actions: Deleuze's Cinematographic Cogito.' Deleuze Studies 2 (2):121-139.

Viegas, Susana (ed.) 2015. 'Dossier: Expanded Cinema', Aniki: Revista Portuguesa da Imagem em Movimento/Portuguese Journal of the Moving Image 2 (1). doi:10.14591/aniki.v2n1.169.

\footnotetext{
${ }^{1}$ Repeating Rodowick's question (2007, 25-87).

${ }^{2}$ The list of books about Deleuze and cinema is immense; see, for example, the extensive bibliography published in Colman 2011, 219-237.

${ }^{3}$ The criticism he presented in chapter IV of Creative Evolution must be understood as a reference to early silent movies, since that book was published in 1907 and based on his 1902-1903 course.

${ }^{4} \mathrm{~A}$ constant presence in the Cinema books, especially in The Movement-Image and the beginning of The Time-Image, Bergson appeared in two of Deleuze's texts of youth, namely in 'Bergson 1859-1941' and 'Bergson's Conception of Difference', both published in 1956 (Deleuze 2003). However, Bergson and the problem of cinema in particular will only appear, together and associated for the first time, in a text from 1976 on Jean-Luc Godard, 'Three questions on Six fois deux' (Deleuze 1995, 37-45).

${ }^{5}$ In his 1997 book On the History of Film Style, David Bordwell analyses the revision of the cinematic concept of modernity.

${ }^{6}$ I would like to thank Malcolm Le Grice for his kind help and permission to reproduce these images.

${ }^{7}$ For a summary of this philosophical interest on expanded cinema, see Viegas 2015, 1-3.
} 